\title{
(VHO) ABEL MPHAGI - THE BAREFOOT NATIVE 'PROPHET' AND 'EVANGELIST' OF VENDALAND: A TRANSITION OF INDIGENOUS BELIEF SYSTEMS AND CHRISTIANITY
}

Mavhungu Abel Mafukata

Free State University

\begin{abstract}
This article details Abel Mphagi's life, ministry and contribution to the growth and expansion of African indigenous Christianity in Vendaland. The article adopts a qualitative 'oral histories' and 'oral traditions' methodological approach. Snowball sampling techniques were used in identifying key informants from whom data were to be collected. Abel Mphagi was a freelance African indigenous Christian preacher who did mission work in the former Vendaland. His contribution to the growth and expansion of African indigenous Christianity in Vendaland remains obscured. This could be because Mphagi was never affiliated to any church group or even affiliated to the Western missionaries who were operating in Vendaland during his time of ministry. Lawrence Khorommbi located Mphagi's grave site at Mphego Village where he was allegedly buried. This article has demonstrated that Mphagi's contribution to the growth and expansion of African indigenous Christianity should receive more attention - especially in academia. Further study should be conducted to deal with certain identified gaps in Mphagi's life and ministry which this article has failed to address sufficiently.
\end{abstract}

Key Words:Ndwambi Khorommbi; Magic; Evangelist; Healer; Myth; Missionary; Lenshina

\section{Introduction}

Most recently I came across a fascinating story told by Peggy Brock about two indigenous evangelists; Arthur Wellington Clah and Moses Tjalkabota. According to Brock (2003), Arthur Wellington Clah was a Tsimshian from the Pacific north-west coast of Canada while Moses Tjalkabota was an Arrernte from central Australia. Brock (2003), says Clah was Christianised by William Duncan in 1850 while Moses was Christianised and baptised by the Lutheran missionaries at Arrernte in 1890. Clah never affiliated himself with any missionary body, choosing to remain independent throughout his preaching of "the Gospel of good behaviour" (Brock, 2003). Moses on the other hand preached "attainment of happiness and eternal life" (Brock, 2003).

Brock (2003) submits that the story of Clah and Moses became popular and interesting when the two eventually became indigenous evangelists to different tribes in their neighbourhoods. Clah and Moses' story subsequently drew increased attention in modern scientific social science research after being popularised by Brock's work. In fact, there has been increased interest in particular of Arthur Wellington Clah as demonstrated by increased scholarly research on his life. Brock (2011) cites amongst others Robert Galois and Susan Neylon, as some of those who were interested in Arthur Wellington Clah's 
expeditions. The story of Moses Tjalkabota on the one hand has not been as popular as that of Arthur Wellington Clah. This disparity could have emerged from the availability of sources reflecting on the two. For instance, the story of Arthur Wellington Clah was easier to access because his 650000 words personal diary on his life and expeditions could still be accessed at the Welcome Library in London (Brock, 2011) while Moses Tjalkabota's story is found piecemeal from different scattered sources, making research about him difficult.

The Clah and Tjalkabota stories bear significant similarities to that of Abel Mphagi; the 'African missionary', 'evangelist'; 'prophet'; 'magician'; 'faith healer' and 'diviner' who lived and practised his 'Christianity' of miracles and prophesies in Vendaland from approximately 1910 to the late 1960s. Abel Mphagi has been mentioned amongst those who assisted Lukas Nthangeni Marole of the Zion City Apostolic Church when he founded the Church at Khalale (Phiphidi Village) on 28 August 1923 (Pretorius 2003). Although Pretorius (2003) mentions the founding date of the Zion City Apostolic Church at Khalale (Phiphidi Village) as 1923, some key informants (Khumela, 2017; Mukhadakhomu, 2016), argue the date of its founding to be 1910. Mukhadakhomu (2016) contends that Marole returned from Johannesburg to Khalale mid-1910 after he had been attacked by a strange sickness during a church service in Johannesburg. Those who were with Marole donated money to send him home to Vendaland. Later, a group of pastors from across South Africa where Marole had previously done mission work, visited him at Khalale during his illness, and that is when the church was founded. The celebrations of the Zionists of the Zion City Apostolic Church were even held at Phiphidi Village in 2016 where the date of the founding of this church is mentioned as 1910. Since Pretorius (2003) mentions Abel Mphagi as being one of the people present at the founding of Marole's Zion City Apostolic Church at Khalale, it is reasonable to assume that Mphagi was already active in ministry at this point - that is 1910 .

Abel Mphagi continues to draw attention beyond that of his peers such as Nthangeni Lukas Marole because of his fascinating and peculiar lifestyle characterised by manifestations of unique miracle-working powers and fulfilled prophesies. However, despite Abel Mphagi's fame and popularity, not much was ever written on his personal life and ministry, for instance. Existing literature (Pretorius 2003), though limited, focuses instead on those personalities who were believed to have founded church groups; for example Nthangeni Lukas Marole, Matsea Paulos Mureri and Edward Lekganyane to mention but a few. Although Mphagi continued to be sidelined and ignored in the scholarship of African indigenous ministries in Vendaland, his unique healing and prophetic ministry would achieve profound significance and popularity amongst many Church historians who would narrate his many stories with appreciation. Abel Mphagi's increasingly strong commitment to his newly-found religion of Christianity demonstrates a religio-cultural transition from indigenous Venda orientation to Westernisation. This transition would also turn out to foster major societal conflict between Westernising locals and ardent Venda religious and cultural conservatives in Vendaland. Mphagi's 'strange' new religio-cultural orientation demonstrates the invasion of Vhavenda orientations by unknown 'foreign' practices, and a reflection of the advent of a changing world in Vendaland's predominantly indigenous religio-cultural space at that time. In addition, since Abel Mphagi's practices were also strange and contradictory to the emerging Westernorientated Christianity of the European missionaries beginning to settle in Vendaland at that time, this brought increased controversy affecting both the conservative European missionaries and the Vhavenda community at large. Missionary theology was neither 'prophetic' nor 'faith or miracle healing' orientations as Abel Mphagi's theology was. The 
locals were also bemused by Abel Mphagi's 'strange' powers of prophesies and miracle healing of both people and animals.

Abel Mphagi was himself a significant religious figure whose contribution to the growth and expansion of Christianity in Vendaland should have received considerable recognition. Yet he never received any such recognition in the retelling and recordings of the history of Christianity in Vendaland and South Africa in general. Although it is hard to tell the reasons for the sidelining of Abel Mphagi's story from the history of the expansion and growth of Christianity in Vendaland, it may still be reasonable to postulate that the writers of that history had little interest in stories of Africans just as it has been norm in (South) Africa to demean African contribution and achievement - especially by European story writers and tellers. Crafford (1991) corroborates this assertion, arguing that "the story of the black pioneers of the [19th century] South African missionary history has never been properly told.

Most often the white missionaries received all the attention, whereas the black coworkers were relegated to the shadowy background" (Crafford 1991:vii). This article brings the story and contribution of Abel Mphagi to the fore with regard to the growth and spread of Christianity in Vendaland. In fact, several people have in the past attempted to bring Abel Mphagi's issues to the attention of modern church scholarship in Vendaland in particular and Africa in general. Realising that the story and issues of Abel Mphagi might completely vanish from public space, the then presiding founder and Bishop of the Charis Missionary Churches in Vendaland, Ndwambi Lawrence Khorommbi started a project on Abel Mphagi which would have re-recorded his story and issues. Khorommbi is said to have met and known Abel Mphagi at Rabali Village in the Nzhelele area where Khorommbi was born and grew up. Khorommbi was captivated by the amazing ministry of Abel Mphagi, and consequently sought to keep an archive about his life and ministry (Ramigo-Ramovha, 2016). Khorommbi managed to trace Abel Mphagi's last days on earth at Mphego Village in the Mphaphuli territory in the eastern part of the former Vendaland where, apparently, Mphagi was finally buried. Khorommbi invited willing church leaders and their church members to build a memorial tomb for Abel Mphagi at Mphego Village. A monument in memory of Mphagi was finally built on his grave site at Mphego Village. However, Khorommbi himself could not complete his massive research work on Abel Mphagi since Khorommbi died in 2002. Immediately after the passing on Khorommbi, this researcher decided to start a fresh research project on Mphagi's life, ministry and influence. The story of Peggy Brock (2003) about Arthur Wellington Clah and Moses Tjalkabota has had significance influence on the researcher to pursue the Abel Mphagi story and issues.

The story of Abel Mphagi bears some striking similarities with the one told by Peggy Brock except that one is an African story while the other is Canadian and Australian respectively. First and foremost, this article describes the African indigenous religiocultural scholarship, thereby indirectly addressing the concerns raised by Crafford (1991) who lamented that African missionary evangelising pioneers of the Christian faith are not accorded the recognition they deserved in the history of Christianity in indigenous areas such as Vendaland. This article seeks to improve African scholarship on religion and culture, for instance by demonstrating that as much as individuals such as Arthur Wellington Clah and Moses Tjalkabota were significant in European religious and cultural history, so are African individuals such as Abel Mphagi. 


\section{Significance of this Article in African Indigenous Religio-cultural Scholarship}

This article narrates and documents the life story of Abel Mphagi - in particular his mission and contribution in spreading Christianity in Vendaland. Abel Mphagi's day-by-day account of his life would give insight not only of his personal mission work and the activities he was engaged in, but would also elaborate on how Christianity evolved from the form of its early years in Vendaland to what it became later - especially during the Abel Mphagi era. The story of Abel Mphagi challenges the false and misleading notion that only the Western Christian missionaries from the European missionary institutions, which had invaded Vendaland in the mid-1800s, had exclusively spread Christianity in that region. This article consideres the fact that indigenous Africans would not so often write their issues - and consequently lost crucial information and knowledge in the course of time risking, in addition, turning both their stories and important characters such as Abel Mphagi into myths. This could explain why African religiosity was regarded mostly as mythical by Westerners and Christian missionaries when they arrived on the continent. Important historical accounts have been dismissed in Africa - especially about Africans and Africa for lack of textualised information and records. This is despite the fact that some of these characters and stories would later emerge genuine, just the same way as Mandevu later emerged as a genuine character and story (Mafukata 2015b). A lesson learnt from this assertion is that some myths - especially in Africa - are therefore actually created from ignorance and misinformation.

This article contends that had proper archived information existed on some of the characters and stories considered myths in some communities in Africa, different assertions and postulations would have emerged instead - and certain empirical postulations would probably have concluded differently. The Abel Mphagi story would elevate and place its issues on the South African agenda of iconic religious figures who became of national interest because of exposure of their issues at this level - something which the Mphagi story failed to achieve in so many years.

The majority of existing literature on religion and culture regarding Africa and its peoples focuses mainly on group practices such as the European Christian missionaries to Africa, ethnic and tribal groups such as the Dinka; Igbo; Bangada; Basotho and so forth, as if African peoples were exclusively 'group' people with no individual significance in society. The story of Abel Mphagi would challenge this distortion on African peoples. This article draws parallels from Arthur Wellington Clah and Moses Tjalkabota for example, with the Abel Mphagi story to demonstrate this assertion. Those who study Africa and its peoples have always deliberately undermined the contribution of African personalities such as Abel Mphagi, mainly because of a Eurocentric approach to retelling African stories and history. This approach portrayed Africa as being a region without its own iconic people and historical stories while European individuals such as Cecil John Rhodes and Livingstone are elevated as heroes and icons of the continent. Africa thus ended with the history of Europeans told in Africa as African history while issues of the indigenous Africans were never told anywhere. In the case of Christianity for instance, countless stories of Western Christian missionaries and their role in the growth and influence of this religion on the socio-economic dynamics of South Africa for instance are told, but stories of, and the role played by indigenous African personalities, are excluded as if they played no role. Having realised that African history told by Westerners is not interested in Africans, and African exploits, there has, been some increased interest amongst African scholars to tell African stories in modern literature and scholarship. For instance, a plethora of literature (Kanu 2014b; Mokotso 2015) began to sprout as early as the mid-1950s commenting on African 
philosophy, religions and cultures in general. The majority of this literature has focused on group issues, not individuals. This article deviates from this approach to telling the African story of an individual.

Apart from archiving of crucial information on the contributions of religious pioneers such as Abel Mphagi in the spread of Christianity in Vendaland in particular, it could be postulated that the telling of these stories would provide a platform for educating concerned communities on their histories, cultures, traditions, religions and so forth - and how at the end the same could have an influence on the social life dynamics of such communities. Nwoye (2011) corroborates this assertion arguing that his work on the Igbo of Nigeria's cultural practices "in particular educate the reader on some ideals and ethos of the Igbo of Nigeria". Based on this context, the Abel Mphagi story provides crucial background in the quest to understand the history and power of religion in influencing the philosophy and social life of indigenous Africans. The tendency in social science research - especially on philosophy, religion and culture for instance - is to focus only on issues of the larger and dominant groups such as the Swazi, Pedi, Zulu and Xhosa (Boeyens 2012) while rendering the smaller groups such as the Tsonga, Venda, Ndebele insignificant. The histories of these smaller groups are therefore relegated to the periphery, and ousted to the brink of extinction. In addition, existing history of these minority groups also is misleading and largely incorrect. For example, with regard to Vhavenda, Abel Mphagi's tribe, Mabogo (1990) wrote that much of what has been written on the history of the Vhavenda is restricted to one or a few tribes while in addition "the available historical information on the Vhavenda is not only incomplete and one-sided, but also highly fragmentary." From these postulations, it could be insinuated that as much as African religions and cultures were marginalised by Westerners and Christian missionaries on their arrival in the continent based on a plethora of factors (Mokotso 2015), there is a growing tendency in Africa - especially amongst Africans themselves - to marginalise religions and cultures of minority tribes. The histories of the minority groups are often excluded, ignored or distorted in clear attempts to undermine such groups socially. With this marginalisation of Africans' socio-cultural references comes 'prejudicial attitudes' and subsequent disrespect of the religions and cultures of the African peoples at large while the entire Africa - and Africans in the diaspora - are invaded by an increased 'penetration of Western civilisation' (Kanu 2014b; Manus 2007; Mokotso 2015).

The story and issues of Mphagi would revive the spirit of preserving African indigenous religious heritage which seems to be dissipating into Westernisation and modernisation as Manus (2007) argued for the Igbo of Nigeria. This article exposes and removes stereotypical tendencies of Western approaches to religion and indigenous peoples' faiths in African communities at large. Westernisation disregarded African cultures, religiosity and religions and portrayed the peoples in Africa as being without religion or any culture (Amoah and Bennett 2008; Hassan 2015). It is on this account that Mbiti (1969) instead defended the notion of Africans having had their own religion for centuries before the arrival of the Western missionaries and their Christianity citing that "wherever the African is, there is his religion. He [The African] carries it to the fields where he is sowing seeds or harvesting new crop, he takes it to a beer parlour or to attend a funeral ceremony; and if he is educated, he takes religion with [him] to the examination room at school or in the university; if he is a politician, he takes it to the house of parliament." This postulation confirms and affirms a long-held consensus in the social sciences that Africans were highly religious because they too have their own religion (Agbiji and Swart 2015). The attitude of the Western missionaries dismantled the religio-cultural heritage of Africans until African 
peoples lost all there was in their religious and cultural orientations (Hassan 2015; Kamwaria and Katola 2012; Kanu 2014b; Mokotso 2015; Nwoye 2011). Western missionnaries were deceptive in propagating a distorted attitude of having brought and introduced religion to the African peoples who had no religion of their own. This is despite the fact that indigenous Africans have had institutionalised religion with clearly defined logics of Supreme God(s). By the time Western missionaries arrived n Africa, African indigenous peoples had been living over so many centuries in utmost consciousness and profound sense of their own deities; mysteries, sacredness and personal inclinations to the divine in their day-to-day life (Kanu, 2014b). Contrary to the arrogant insinuations of Western missionaries, it is evident from reviewed literature that religion in Africa was not an invasion of the European missionaries. This is what the European missionaries had propagandistically wanted African indigenous peoples to believe by systematically propagating this falsehood to "reduce all the indigenous beliefs to little more than animism and ancestor worship" (Amoah and Bennett 2008) or mere primitivism; paganism; heathenism and practice of magic (Kanu 2014b). The marginalisation of African religions by Western and Christian missionaries who invaded the region from Europe under various religious and political commissions in particular, has had a profound impact on the practice of religion in Africa. For example, indigenous African Christianity - especially the one characterised by the theology of prophesy and healing miracles - was categorised as 'practice of witchcraft', 'anti-civilisation' and 'paganism' by the missionaries (Ndung'u 2009). Indigenous African personalities who practised prophecy and other supernatural miracles such as the healing of the sick have for over the centuries been categorised as 'messianic unchristian faith healers' and 'witchdoctors' amongst others (De Visser, 2011; Fernandez, 2001; Khorommbi, 2001; Ndung'u, 2009).

The missionaries would argue that such personalities only rose or took advantage of a certain social difficulty affecting certain communities at certain times and spaces - citing social, economic, political and/or psychological difficulties for example (Ndung'u 2009). In other words, the missionaries viewed African indigenous religious leaders as opportunists. This postulation undermines the fact that religion in general has most constantly been utilised by both European and African indigenous religious believers to address emerging difficult societal experiences. This article posits that both Western and African indigenous Christianity were meant to address some of these societal complexities. Moreover, when Western Christianity for instance was perceived to have failed to address certain societal complexities as they would affect society from time to time, as postulated by Ndung'u (2009), this instead strengthened the continuity of African indigenous religions and cultures as substitutes.

The emergence and mushrooming of indigenous African Christian missionaries such as Abel Mphagi and others which continued right through into the modern era could be confirmation that the strength of African religion and culture has been the guiding philosophy underlying African religious and cultural lifestyles and practices which these individuals only managed to preserve. Although it emerged that Western religion eventually became more dominant over African indigenous religion(s) beginning inception of Westernisation and colonisation of Africa up to post-colonial Africa, African indigenous religion remained an influential factor of social life amongst many in Africa with many indigenous Africans remaining deeply rooted in their African traditional value systems with patterns of social life still highly influenced and dictated by these value systems (Hassan 2015; Mulaudzi 2007). This article demonstrates that African indigenous personalities such as Abel Mphagi would therefore remain influenced by these dictates in their perspective of 
religion. These personalities may not even see any contradiction in the practice of religion; especially with regard to Western Christianity and African indigenous beliefs and practices on the one hand. In other words, this article goes further to demonstrate the differences between African indigenous missionaries such as Abel Mphagi and the Western missionaries which lie with the fact that African indigenous missionaries such as Abel Mphagi did not transplant a faith that [he] had received from the missionaries (Kumalo n.d) but only interpreted the same message of Christianity to these communities in 'their language and cosmology' (Kumalo n.d). This is the point missed by those who advocate for the supremacy of the Western version of Christianity over the African indigenous version of Christianity as propagated by personalities such as Abel Mphagi.

This article also reasons the authority of the majority of current existing literature; amongst others Van Rooy (1996) which seems to insinuate that modern church history especially in Southern Africa - is influenced only by the arrival of European and American evangelists and missionaries, whereas the Abel Mphagi story postulates a view which might be contrary. From the perspective of Van Rooy and others, there arises the danger of absolutisisation of a European perspective of religion and the subsequent recognition of its theology as being absolute and superior over African religion as if an African indigenous perspective of religion and its subsequent theology are non-existing. A plethora of literature (Khorommbi 1996; Khorommbi 2001; Ndou 1993) however began to emerge in the last three decades refuting this insinuation. For its discourse, this article adopts a clearly set method to achieve its aim and objectives. The adopted method is subsequently briefly explained.

\section{Method and Instruments}

\section{Statement of the Problem}

Modern Christian Church history in indigenous African communities such as Vendaland disregards and sidelines the role played by African indigenous individuals such as Abel Mphagi in the growth and expansion of Christianity in the region. That history mainly focuses on the contribution of, and role played by the Western and European missionary individuals. The contribution and role played by these Western missionaries in the growth and expansion of Christianity in the region, is told as if there were no Africans who had played any role and made no contribution whatsoever to the growth and spread of Christianity in the region. On this, Kumalo (n.d) argued thus: "There is a need to tell the stories and experiences of the native missionary agents who were the first Christian educators in their communities. When we do that we are not only liberating their silenced voices, but we are also liberating the contribution they made to the Africanisation of the church which had initially been biased in favour of Euro-centrism and the denigration of African culture." Kumalo (n.d) goes further to argue that "It must not be assumed that the white missionaries alone were responsible for the conversion and conservation of African members... It is noteworthy that throughout the century of missionary advance it was often African converts who enthusiastically initiated new work in remote areas." Based on Kumalo's argumenttation, this article demonstrates that African indigenous missionaries such as Abel Mphagi for instance, also made significant contributions to the growth and expansion of Christianity in the region. 


\section{Aim and Objectives of the Article}

The main aim of this article is to investigate, highlight and present the life and ministry of Abel Mphagi because the same has not received the recognition it deserves - especially in literature and debates concerning the growth and expansion of Christianity in Vendaland. The specific objective of this article is to demonstrate the contrast between African indigenous Christian missionaries and their practices and Western missionaries operating in Vendaland during the Abel Mphagi era.

\section{Setting of the Article}

The study was undertaken in the Vhembe District of the Limpopo Province in South Africa. The focus of the article is on Abel Mphagi. From the beginning, to gather data for Abel Mphagi's story was always going to experience insurmountable complexities and constraints with regard to availability of reliable, authentic and valid data. This differentiates the story of Abel Mphagi and that of Arthur Wellington Clah, as told by Brock (2003), because Clah is said to have kept a diary which documented his adventure and life sometimes from 1859 (Brock, 2003). Unlike Clah, Abel Mphagi never kept a diary of his life and missionary work therefore making his story heavily reliant on oral sources obtained from those who might have known him personally, or heard of him, as his story was told from generation to generation over many decades. This article adopts the qualitative historical research design. According to Hassan (2015:194), historical research design could "enable the researcher to systematically collect, evaluate, and describe data to explain, and understand actions or events that occurred sometime in the past" - Abel Mphagi's story is mainly about events of the past, and thus fits this methodological perspective. This article is therefore based on the 'oral histories' and 'oral traditions' methodological postulations highly favoured and recommended by Hassan (2015) and Boeyens (2012).

First, the choice of the Boeyens' methodological approaches to the Abel Mphagi's story was based on the fact that the approaches provide the discourse of this article with an interdisciplinary approach to solving the article's problem. According to Boeyens (2012:9), oral histories could be defined as "memories and recollections of the individuals who experienced or witnessed in their own lives the events they relate," based on this definition, it is evident that this article would depend much on key informants who would have to provide memories and recollections of their personal experiences and witnesses of the life, and exploits of Abel Mphagi. On the one hand, the 'oral tradition' approach as applied by respected African oral traditionalists such as Jan Vansina, David Henige and Joseph Miller, would extend the scope of the Abel Mphagi story to 'beyond living memory' periods (Boeyens (2012). This is because 'oral traditions' are known to 'accordingly extend back' their accounts (Boeyens, 2012) as it would be needed in the Abel Mphagi account. Primarily, the 'oral traditions' would also provide this article with the appropriate framework for the analysis of events relating to Abel Mphagi's story.

Through 'oral traditions,' the context of Abel Mphagi's story was developed within the 'recent past,' 'foundational accounts' and the 'middle periods' categories of the 'oral tradition' approach (Boeyens, 2012). The 'recent past' allows the story to develop from recollection of events some generations back, and these events are then related and dated, and in the case of sites, these sites are remembered and located. Some of the issues around Abel Mphagi may have happened a few generations back therefore necessitating this approach. Evidently the discourse of the story reveals significant mythical references. The 'foundational accounts' approach provides the article with the best way possible to address these mythical characterisations in the story. The 'middle periods' allows for the analysis of 
the events of Abel Mphagi's life and ministry which happened in what Boeyens (2012) calls the 'floating gap'; that is the period between the 'distant mythical past' and the 'recent past.'

The premise of this approach, as has been illustrated above, points to a story lacking in archived material and sources for data collection. Methodologically this fact necessitates a departure from common the methodological approach of document analysis as adopted by both Brock (2003) and Nwoye (2011) in similar studies needing reconstruction of the storyline. A list of the names of those who had known and lived with Abel Mphagi was constructed through snowball sampling techniques. Most of these informants were found scattered around Ha-Mphego, Thohoyandou, Nzhelele - especially Dopeni, Gavhe, Mandala and Mauluma villages - where Mphagi seems to have spent much of his time, and also practised more of his ministry than elsewhere during his mission. After moving around these villages for approximately three months trying to locate some of the mentioned possible informants, it became evident that the pool of those who had lived and personally interacted with Mphagi had become limited. Some of these possible informants had long since died while others could simply not be traceable. Amongst those still alive, there were others who could only remember insignificant information which could not have assisted the article much. Finally, only eight informants were found to be credible enough to provide reliable, authentic and valid data.

Individual interviews were subsequently conducted with the selected eight participants as key informants. Key Informant Interviews (KIIs) were preferred over Focus Group Discussions (FGDs) because of the distance complexities between the sources. It could not be possible to conduct Focus Group Discussions (FGDs) for data collection because of constraints of resources required to transport those people to a particular meeting place for discussions though it had seemed the most desirable approach at the inception of this study. Crucially, though, was that Key Informant Interviews (KIIs) were still opportune and effective enough to supply the required reliable, authentic and valid data from the eight participants. Data from the interviews were recorded as field notes for analysis. Collected data were compared and matched for similarity. Unmatched and non-correlating data were discarded as being unreliable mainly because its reliability and validity could not be guaranteed.

During the interviews, some crucial observations were made. For instance, some similar data between sources emerged although it could be deduced that some of that data could have easily made entry into the Abel Mphagi story, however, not necessarily having had happened. On this, this article considered the caution asserted by Mafukata (2015a) who, when quoting O'Brien, Remenyi and Keany (2004), advised historiographers and ethnographers thus "history stands or falls on the researcher's ability to obtain a range of reputable and credible sources of evidence." Where such challenges were met, it was determined that it was not possible to reject and discard some data based on the researcher's 'doubts,' hence the researcher borrowed from O'Brien et al. (2004) who argued that "Each researcher will have his or her own set of criteria for accepting a piece of evidence as relevant and credible." Data illustrating Abel Mphagi's exploits which could not have happened in the other village(s) for the other respondents to have known about them, were found to be consistent to his known exploits and accepted into the data base. This approach is consistent with the advice by O'Brien et al. (2004) who argued that there remained huge possibilities that certain not so reliable or valid data 'enters into this process' (Mafukata 2015a). In the main report, such data as is mentioned here, is accordingly highlighted. Meanwhile, similar data emerging between sources, which did not convince as being 
authentic, but easily made entry into the Abel Mphagi story over the years (however not necessarily having happened) was also highlighted.

Finally, analysis of the collected data involved identification of certain patterns and themes reflected in it; the data coded and synthesized (Hassan 2015). There emerged substantial data which had to be discarded because of unreliability. Accepted data were developed and written into the main report as presented below.

\section{Results and Discussion}

This sub-section presents the results of this research. The results are structured and presented under clearly-demarcated sub-headings, with special focus on Abel Mphagi's early life, origin and Christianisation, Mphagi's philosophy of life towards animal life, his home and family life, his mission, Abel Mphagi and his prayers, how he was viewed by locals; the comparisons between him and others, his strange Christianity and his strange cultural practices; the clash of the White man's religion and the Black man's culture and tradition, and Mphagi's yet unanswered questions on his life and spirituality.

Before delving into Abel Mphagi's story line, it is critical to determine the authenticity of this story and Abel Mphagi, the character. Firstly, the story of Abel Mphagi therefore in addition demystifies the character. Evidently, it was possible that some of the alleged exploits of this man, such as prophesies and healing miracles, were mere myths. Whereas Mphagi is genuinely somebody who lived as explained elsewhere in this article, it could be that portions of the storyline could have been unintentionally planted by those who told his story over the years from generation to generation. Alternatively, it could be that some parts of Abel Mphagi story were corrupted through the discourse of the story as it was being narrated from one generation to another, and over this seemingly extended period over which the story was being told. These are traits in historical narratives. Unlike in Mandevu where both the character 'Mandevu' and the story could have been mythical (Mafukata, 2015a), both Abel Mphagi and his story have sufficient evidence pointing to their existence. His existence is confirmed in this article through the presentation of his early life and geographical origin in Vendaland for instance. This information is now discussed.

\section{Abel Mphagi's Personal Profile}

The personal profile presents Abel Mphagi's age, place of origin in the greater Vendaland and his 'foreign' name 'Abel'. Key informants could not be particular about his age. However, consensus was that he might have been older than Nthangeni Lukas Marole by at least six to eight years. Marole was born in 1887, and he was 87 years old when he died in 1974 (Pretorius 2003)). Mphagi could have been born between 1879 and 1881 considering what the key informant had agreed on with regard to his age. Mphagi was still frequenting Mauluma Village in the Nzhelele area approximately 1958 (Mukhadakhomu 2015; Nematshema-Nemauluma 2015). Khumela (2017), however, adds that she last saw Mphagi at Malavuwe Village in 1962 when he was attending a church service at Abel Simba's homestead. Although key informants would not be conclusive, consensus was that Mphagi was still alive in 1974 when Marole died. Many of Marole's friends and peers - 38 in number - attended his memorial service which was held the night before his burial. However, because Mphagi was said to have been too old at the time, Mphagi could therefore not attend both Marole's memorial service and funeral at Khalale (Phiphidi Village) in 1974. This article thus concludes that by the time Marole died in 1974, Abel Mphagi could have been anything around 95 years old. Mphagi was himself to die at an 
unknown venue and date. All there is in the public is that Mphagi was buried at Mphego Village on the far eastern side of Vendaland in the Vhembe District of Limpopo Province, South Africa. It was the late Lawrence Khorommbi who located Abel Mphagi's grave site at Mphego Village during his unfinished research project on Mphagi. A tombstone was erected on Mphagi's grave site at the initiative of Khorommbi.

Information of where Abel Mphagi was born or where he came from was contradictory. All that informants could recall was that Abel Mphagi was a native of Eastern Vendaland possibly from Ha-Tshivhasa. All the informants could not be particular about Mphagi's home village. Others argued that Abel Mphagi was born, raised and grew up at Tsianda near Tshakhuma while others contended he was a native of Dzimauli, Ha-Rambuda. Locals seem to have known him as Vho (Mr) 'Abel' Mphagi. In Vendaland, as has been custom throughout generations, it might be that 'Abel' was a name given to Mphagi because the most common practice was to give children indigenous Tshivenda names at birth.

The critical question is therefore "who named Mphagi 'Abel', and why?" Agyekum (2006) reveals that amongst indigenous African communities the naming of newly-born would be influenced by the culture, philosophy, thought, environment, religious and linguistic orientations of the respective peoples. Whatever name is given to a newly-born would often be symbolic and reflective of certain cultural, philosophical, religious experiences of the particular people; be that family, clan or tribe. The naming of a baby in indigenous African communities goes beyond mere differentiation, recognition and knowing who this person is amongst others. Therefore, Abel Mphagi must have had an indigenous African name reflective of these sentiments. The name 'Abel' contradicts common practices amongst Mphagi's Vhavenda tribe. Just as in the case of the Akans of Ghana, as explained by Agyekum (2006), at birth, the Vhavenda would also have their own baby naming custom which Abel Mphagi's family would have been influenced with when giving him a name. Therefore "What was Abel Mphagi's indigenous African name from his people?" or "Did Abel Mphagi denounce his Tshivenda traditional name after Christianisation as most Christianised individuals would do - especially at the height of missionary Christianity and the spread of Westernisation in Vendaland?" However, looking at Mphagi's name, 'Abel', it could be postulated that Mphagi could have come from a religious family. Customarily, amongst the Vhavenda tribe where Abel Mphagi hails from it could have been strange for Abel Mphagi's family to have named him 'Abel'. 'Abel' is in fact from European Christian missionary and/or Westernisation references.

The European Christian missionaries are known to have given new Christian names to those Africans who would believe and accept their Christian faith - especially after such people were baptised (Mokotso 2015). Christian converts were expected to ditch their indigenous names to adopt the new Christian names (Mokotso 2015). It could be that 'Abel' was a name given to him by the masters of Mphagi's new faith, or at least the spreading Westernisation in the Vendaland area. This assertion, however, could not satisfactorily explain the origin of Mphagi's Christian name 'Abel' since Mphagi could not be identified with the practices and culture of the European missionaries by affiliation. Possibilities remain high that Mphagi could also have received his name from the spread of Westernisation in the Vendaland region and not necessarily from Christianisation. Friends of Abel Mphagi such as Nthangeni Lukas Marole also had these 'Christian and/or Western' names. For instance, Nthangeni Marole was named 'Lukas'. What is critical is that had the Mphagi family not been influenced by missionary Christianity or increasing Westernisation, Abel Mphagi would have had a Tshivenda name at least. Despite an extensive search for Mphagi's indigenous name, no informant ever remembered Mphagi as having had any 
indigenous name. The fact remains that Mphagi must have had an indigenous name at some stage of life, only that such name remains unknown at this point of this inquiry. Therefore, Abel could have been an adopted name which Mphagi acquired when becoming Christian; alternatively he may have acquired this name through Westernisation in Vendaland.

Abel Mphagi stayed in no one particular place or even household, and he had no known relatives where he stayed where he was on mission. When one listens to narrations on the life of Abel Mphagi, one might even postulate that this man may have been more of a street wanderer than he would have been a 'prophet,' or 'evangelist,' as many believed. Although Mphagi would move from village to village preaching, prophesying and performing healing miracles on those who were sick, there were certain places he would frequent more than others. He was popular at Tshituni tsha Ha-Gavhe in Nzhelele where he would routinely visit the Tshihwela household. At Dopeni Village, he would often visit Jakubosi Tshilebvu Matshidze's compound. Here Mphagi would also attend church services and meetings usually held in the evenings. At Mandala Village, Mphagi would be received by Luvhengo David Muronga while at Mauluma Village for instance, locals such as Jakubosi Raphalalani and Piet Khunwana Nematshema, in particular, would receive him often. Most of Mphagi's hosts while on mission kept him on 'ubuntu' or 'vhuthu' (Dowden 2014). This is presumably because in most African indigenous communities relations were more important than genealogy.

In Africa - especially amongst the Vhavenda of northern Limpopo in South Africa people would stay with non-relatives in their households for years without mentioning their relations. Africans, unlike Europeans, lived from communalism not individualism (Dowden 2014). This stems from the fact that "in Africa families acquire people" (Mashau, 2012) unlike in Europe where "families shed people" (Dowden 2014). Even though Mphagi would have no family where he went for mission, he would still manage to live peacefully and as part of the broader society in those places based on these sentiments. However, in modern day Africa the African culture of communalism and family extensionism is being challenged by disintegration and extinction. This is because there is a growing entrenchment into broader society in African communities by those orthodox social systems imported from the former colonising European regions. These Western and Christian entrenchments have often resulted in the demobilisation of African lifestyles, traditions and cultures which promoted communalism and family extensionism replacing the same with emphasis on 'relatedness' of individuals in order to live. The introduction of multiculturalism in Africa corroded the African viewpoint of what family is. Mphagi was 'family' wherever he went because of 'residence' with those people, not 'relatedness.' Mashau (2012) shows the impact of Africa's newly found multiculturalism on the African social systems and culture as introduced and entrenched by Europeanism and Christianisation of the African peoples. Uche (2014) also documented the impact of multiculturalism on the African peoples, such as the Igbo of Nigeria. Had it not been African philosophy on how 'family' is defined, Abel Mphagi would have found his life and mission seriously compromised. Hosts may have regarded him a stranger, but instead Mphagi was regarded family.

On marriage and family life, some informants were of the opinion that Abel Mphagi was once married, but abandoned the marriage because he wanted to serve God without having to worry about supporting a wife or children. Some informants went as far as claiming that he later married a woman only called Miriam of Duthuni Village whom he met while on mission at Mandala Village (Rakumbani-Luthaga 2016). Despite the 
researcher's efforts to establish who this Miriam was Mphagi had married, no further information on her was ever found.

Abel Mphagi was a highly respected, self-trained missionary with no formal Bible school training. His lack of formal training in mission work may be explained from the fact that the majority of African preachers and missionaries at the time would never have had the opportunity to attend Bible School as they were considered uncivilised, primitive and pagan by the missionaries who had considered themselves the only authentic versions of Christianity in Vendaland. For Abel Mphagi and others like him such as Nthangeni Lukas Marole, preaching was part of worship. Therefore, he could not have gone to Bible School to train as a minister. Some respondents opined that one could not have gone to Bible Schools during the time of Abel Mphagi to learn worship. It would have been strange. However, amongst other indigenous African Christian groups such as Zionists, some informal training of those aspiring for Church leadership positions would be conducted from time to time (Pretorius 2003).

Key informants described Abel Mphagi widely; some opining that he was a 'preacher', 'evangelist', 'faith healer' and 'prophet'. Mphagi was not affiliated to any particular Church group although much of his life involved doing some ministry with the late Nthangeni Lukas Marole of the Zion City Apostolic Church at Khalale (Phiphidi Village) (Pretorius 2003). Marole was to later become the head of the Zion City Apostolic Church at Khalale (Phiphidi Village) (Pretorius 2003).

\section{Abel Mphagi's Christianisation}

In the same way as Abel Mphagi's early life is shrouded in mystery, his Christianisation is also clouded in controversy and mystery. First, information on how he was converted to Christianity never emerged in the interviews. Secondly, no informant had any information on whether Mphagi was baptised or not. Baptism was considered one of the indicators of commitment to Christianity - especially amongst the European missionaries. However, that Mphagi was preaching Christianity made the informants believe he was Christianised and/or baptised. What deepens the mystery is that Abel Mphagi's is not mentioned amongst known Vhavenda early converts of the Christian missionaries in Vendaland. In addition, his name is also not amongst those of others such as Lukas Nthangeni Marole of the Zion City Apostolic Church who were said to have been converts of John G Lake. Abel Mphagi is, however, mentioned later in Marole's missionary commitments - especially at Khalale (Phiphidi Village) where he had contact with Marole and others at the founding of the Zion City Apostolic Church (Pretorius 2003).

The early natives to receive the message of the White missionaries in Vendaland are Johannes Mutshaeni Netshiongolwe and his wife Mufanadzo Johanna Mutshaeni Netshiongolwe who were the first Vhavenda to be baptised and they also worked closely with the Berlin Mission at Maungani between 1872 and 1877 (Munyai 2007). Johannes Mutshaeni Netshiongolwe died on 4 November 1876 just a year before the baptism of his wife Mufanadzo Johanna Mutshaeni Netshiongolwe at Maungani's Beuster Mission in 1877 (Munyai 2007). Up to this point, it appears Abel Mphagi was never a known entity amongst these converts of the Maungani mission. There is no known empirical literature mentioning one Abel Mphagi as a believer of the missionary's message or someone who emanated from these missionary circles. Just where Abel Mphagi's Christianisation came from remains unclear, and largely a mystery.

Mphagi's Christianisation would have shared some light on what had informed his theology and missionary work. Therefore, 'where did Abel Mphagi get his theology from if 
not from these European missionaries?' This research pursued the course of this question by trying to establish where Abel Mphagi could have received the Christian faith from. If not then from the Western missionaries, does this suggest that Mphagi could have received this from 'other' sources which are unknown yet, so far in Christian history in Vendaland? Is there any possibility of indigenous Africans who may have accessed Christianity through these 'other' sources - do they exist at all apart from the known European missionaries in Vendaland? The mystery created by these questions continues to deepen considering the dissimilarities of the theological orientation and context of missionary practices between the European missionaries and the likes of Abel Mphagi for instance. Christianity as practised by Mphagi and other indigenous African religious figures seems to have been highly hybridised, and in fact distinct. In other words, Mphagi and other indigenous preachers of his time practised a combination of Christian missionary principles and African culture. This is because "many Zionists [a group Abel Mphagi spent most of his time with] feel that certain things from the old tradition must be included [when they become Christians]. They retain much from their culture" (Pretorius 2003:162). Although these people had become Christians, some of them would still hold on to their indigenous beliefs and customs such as polygamous marriages (Pretorius 2003). This was not unique only in South Africa but elsewhere in African where clashes of European Christian Missionaries and African Traditional religious beliefs had been widely reported (Hassan, 2015).

The absence of information on Abel Mphagi's Christianisation could be suggestive of an ordinary transition from his indigenous faith to Christianity. Contrary to the Christianisation of Abel Mphagi which remains peripheral from the limelight of others which are glorified, the Christianisation of other African indigenous spiritual personalities, who were raised during the seasons of European missionaries in Africa but went on to remain distinct from European missionary philosophy and teachings such as Alice Lenshina of the Lumpa Church in Zambia and Johannes Richmond of the Corinthian Church, amongst others, is characterised by inexplicable encounters with some 'supreme powers' who have had profound influences on the lives of these personalities.

The Christianisation of most of these personalities is highly dramatised while Mphagi has a quiet entry and exit in the Christian mission. However, some of the encounters apportioned to the Christianisation of some of these personalities would in all likelihood never have happened. However, this article does not interest itself with the truthfulness of such claims. For example, Johannes Richmond was apparently healed from a strange boil by being 'cooked' in a boiling pot or 'boiled' in a pot by community elders (Wepener 2015). In addition, Richmond is said to also have spoken in strange tongues after he had been cooked (Wepener 2015). Engenas Lekganyane is said to have received enormous miracleworking which made him pray for a dead dove - and the bird came back to life (De Visser, 2011). In cases such as that of Nongqawuse, the daughter of Mhlakazi of the Gealeka, who initiated the historical great Xhosa cattle-killing spree of 1856 after some strange prophesies obtained from "people who died long time ago" (Peires 1987), observations are that such characters are influenced by encounters with 'supernatural' visions, dreams, miraculous recoveries from dreadful diseases, or personal encounters with supposed supreme beings who deliver prophecies to be taken to people. Except in a few cases of figures such as Engenas Lekganyane of the ZCC who was Christianised during the missionary work of John Alexandra Dowie of the Zion City movement of Illinois in the United States of America (De Visser 2011) and others such as Emmanuel Milingo of the Roman Catholic Church in Lusaka, Zambia (Mildnerová 2014), most of the African 
indigenous prophets' Christianisation through Church or the European missionaries is blurred. These figures seem to have been quasi-Christians lacking in practical background of the European Christian missionary systems as practised and advocated for by European missionaries in their various missionary stations, and later amongst Calvinistic Churches which were to emerge and spread across Africa. It is evident that the religious practices of some of the African personalities such as Abel Mphagi would later create their own African version liturgical rituals and traditions (Wepener 2015).

These rituals and traditions were mostly operational, and therefore adopted within their respective formations; that is, African Independent Churches (AICs) in particular. These rituals and traditions were mostly not consistent in form and practice with missionary Christianity, and the differences pitted the European Christian Missionaries against the African indigenous Christian formations in particular (Hassan 2015). This confrontation explains the desire of the European missionaries to belittle and dismiss the African indigenous Christian formations as non-Christian; a perception which seems to have been elevating European missionarism to superior status above African indigenous Christian formations (Hassan 2015). Emerging African indigenous personalities such as Abel Mphagi who would continue to rise throughout the spreading of Christianity, found it difficult to cope with the discriminatory systems of the European missionaries, and therefore provided a 'centrifugal force' amongst these African religious cohorts, which from disillusionment began to integrate African Traditional beliefs with Christianity rather than to totally reject and abandon Christianity (Hassan 2015).

This may explain why Abel Mphagi's practices were not consistent with the European missionary version as practised in various mission stations in Vendaland for instance. However, most crucially, Abel Mphagi's Christianisation does not seem to bear any of the so-called supernatural encounters at his Christianisation experiences as has been associated with the rest of the emerging religious cohorts such as Lekganyane. However, miracles and prophesies through supernatural endowment in Abel Mphagi's life and mission were later to become evident in his life. This leads us to another critical question: "where did Mphagi get his prophetic and healing power from?" This article tries to establish issues around this question by observing Mphagi's spiritual life and practices.

\section{Abel Mphagi's Spiritual Life and Practices}

Abel Mphagi was an ordinary villager who was highly respected by the locals where he ministered because of his miraculous healing powers and prophesies. His powers are said to have derived from his powerful prayer life and long fasting periods (Muvhali 2016; Nematshema-Nemauluma 2015; Ravhanna 2016; Rakumbani-Luthaga 2016). Mphagi is remembered for his extended periods of fasting; abstainment from consuming foods. The majority of respondent key informants argued that Mphagi's miraculous healing powers came from his extended fasting and prayers in the mountains.

Key informants were of the view that Mphagi may have been surviving on wild foods, fruit and vegetables because he was never one to be seen by any consuming meats and 'Vhuswa' (porridge) as was common amongst Vhavenda men and the rest of the locals. 'Vhuswa' (porridge) is the staple food of Abel Mphagi's native tribe of the Vhavenda. However, Rakumbani-Luthaga (2016) vehemently contended against this view asserting that Abel Mphagi did consume 'Vhuswa' (porridge) - although rarely. Contrary to popular assertion, Rakumbani-Luthaga (2016) argued that Mphagi would, on routine visits to her uncle Luvhengo David Muronga who was pastoring an Apostolic Faith Mission Church (AFM) at Mandala Village in the Nzhelele Valley, consume Vhuswa' (porridge). 
According to Muvhali (2016) and Nematshema-Nemauluma (2015), Mphagi would on occasion carry his lulege (tin container) which he used to convey drinking water. These informants argued that Mphagi would also use this water to brew his tea. They argued that Mphagi liked his tea. Muvhali (2016) and Nematshema-Nemauluma (2015), however, confirmed that Mphagi survived mostly on wild fruits - especially when praying at Tshilapfene, Mapate, Tswime and Vuvha mountains. Several informants (Muvhali 2016; Nematshema-Nemauluma 2015; Ravhanna 2016; Rakumbani-Luthaga 2016) also revealed that many still believe that Mphagi's newly-found habit of consuming foods - especially tea and 'Vhuswa' (porridge) - had greatly diminished his prophetic abilities and healing powers. They contended that these were habits which brought his ministry to an abrupt end. The consensus by Muvhali (2016), Nematshema-Nemauluma (2015), Ravhanna (2016) and Rakumbani-Luthaga (2016) was that Mphagi's consumption of these foods made him unable to perform his miracles.

Locals knew that once Mphagi got to the mountains to fast and pray, he would return to perform great miracles in the villages. However, this was not the case when Mphagi was on these foods. Apart from his lifestyle of extended prayer and fasting, Mphagi had a unique way of demonstrating his spiritual prowess. It appears Mphagi's approach to ministry was similar to that of Clah and Moses, as has been mentioned earlier in this article. Clah's preaching focused on "the Gospel of good behaviour" (Brock, 2003), while Moses on the other hand focused on the "attainment of happiness and eternal life" (Brock, 2003). Mphagi, like these two, also had a particular focus on preservation of life for everything that lives. He taught people to respect human and animal life.

\section{Abel Mphagi's Affection for Animal Life}

During Mphagi's era, the majority of households would survive on milking their cows, but Mphagi would discourage them from doing so because they would be consuming what the calves must have been surviving on. Some key informants submitted that Abel Mphagi would not have eaten meat either because he preached against the slaughtering of animals. To Mphagi, slaughtering animals was actually practising violence against animals. In fact, Mphagi called that 'tshituhu' on defenceless animals. Mphagi would argue that slaughtering of animals was cruelty against God's creation. Mphagi's assertion in this case may, however, be equated with the behaviour of other spiritualists across cultures and religions in larger society in South Africa. Spiritualists such as "the practising Zulu shaman" Credo Mutwa (Sheikman 2004) for example, would also reveal similar belief systems on animal life. Abel Mphagi, like Credo Mutwa, may not have been influenced by Christianity largely because the Christian faith is not known for advocacy against animal slaughtering as violence and cruelty to animals. They could have been influenced by African philosophy instead. Malcolm Draper has satisfactorily demonstrated the depth of African philosophy, culture and value systems on the response and interaction of Africans with nature (Draper 2003).

In view of the Draper postulation - and the one submitted by this article on Abel Mphagi's affection for animals for example - a reasonable inference could be that Abel Mphagi could have been influenced more largely by African philosophy, culture and value systems as regards nature - and animals in particular - than with his religious conviction. Despite Mphagi's having founded a 'new' religion in Christianity, his day-to-day social life was still very much expected to be influenced mainly by his native philosophy - especially with regard to respect for the lives of animals. Even if Mphagi had become immensely influenced by his 'new' religion, it was highly unlikely that he would have ditched every 
aspect of his traditional and cultural life. This is reflected in Mphagi's continuous upholding of the cultural values on animal life which he demonstrates by his protection thereof. It has been said that the spiritual practices of Africans are governed by their cultural and traditional philosophy. In other words, their spirituality would be influenced from what Africans "eat (or cannot eat), the way they farm, do everyday chores, hunt, make tools and clothes, arrange themselves in families, marry, divide work among family members, educate their children, treat illness, and bury the dead" (Christian 2014). In other words, as an African, Abel Mphagi could in fact be said to have been greatly influenced in his viewpoint of nature in relation to animal life by the views or philosophy of his tribal roots rather than his newly-found Christianity. Just as has been postulated (Kanu 2014a; Njoku 2004) that Africans are highly obsessed and influenced by their religions and cosmological viewpoint, Abel Mphagi is not expected to have been different. His practice of religion would always reflect an inclination towards his African cosmological viewpoint - and hence his viewpoint on nature and animals in particular. To shed light on this, it became critical to profile Abel Mphagi's missionary context and content.

\section{Mphagi's Missionary Context and Content}

This section seeks to profile Abel Mphagi's mission, its context and its content. This section attempts to investigate what exactly Mphagi's mission was and how he im-plemented it. It seems all the religious personalities had a particular mission, content and context. The Clah and Moses story in Brock (2003) demonstrates this assertion. Both are known for having had particular missions, content and context. In South Africa for example, Ntsikana the son of Gaba (1780-1820) who was a Xhosa preacher and prophet focused on the establishment of a Christianity inclusive of, and friendly to African tradition and culture amongst his Xhosa peoples of the Cape (Kumalo 2014). Ntsikana could be described as a 'political' activist of transformation of religion in South Africa, who was informed by the desire to achieve 'political consciousness' amongst native Xhosas of the Cape. His mission was to establish and lay "a foundation for an African form of Christianity" as a "Pioneer of African form of theology and intellectualism" (Kumalo 2014) in Xhosaland. Abel Mphagi's mission was to preach the simple Gospel of Jesus Christ to his unenlightened natives. Unlike Ntsikana, who showed great focus on religio-political activism of 'Black conciseness and liberation theology' amongst the Xhosas by wanting to bridge the gap between African culture and religion and Western Christianity to create 'African form of Christianity' (Kumalo 2014), Abel Mphagi instead focused on a simple Gospel of salvation and demonstration of healing miracles without being a vocal political activist such as Ntsikana. The next crucial analysis was to determine how Abel Mphagi conducted his mission. How did Mphagi convey his message to the audience in his vast geographical area of dispersed villages considering communication and other logistical limitations at the time? This section tries to answer this question.

Abel Mphagi's mission was self-supported. Unlike the European missionaries in various mission stations in Vendaland who were supported by their commissioning authorities and organisations, Abel Mphagi was never supported in his mission, and therefore lived, and conducted his mission work by his own efforts. Wherever Mphagi would arrive to preach, he would spend the day with the villagers but avoided depending on them for support and daily upkeep. Mphagi spent most of his time with the people where he preached the Gospel from one household to the other, and from one village to the next. During the day, Mphagi would walk from village to village where he would spend time preaching to the villagers and also praying for those whom he would find sick - including animals. During the 
evenings Abel Mphagi would retreat to the mountains where he would spend time in caves - sometimes sharing abode with dangerous animals such as leopards and venomous snakes such as mambas and huge ones such as pythons. Whenever Mphagi found any animals in the caves, no matter how dangerous they were, he would never chase them away from their habitat. He would sleep there sharing the cave with the animals after commanding them not to harm him. Mphagi would give instructions to the animals in his native Tshivenda. The animals would respond accordingly as though they literally understood his language and instructions. It is said Mphagi would say to the animal(s) "inwi ni edele henefho, nne ndi do edela nga afha vho," meaning "You sleep that side as I sleep this way also." Mphagi would be heard praying "Mudzimu wa Aburahamu, Mudzimu wa Yakobo, Mudzimu wa Isaka...Vho inwi mimuya ya diabolo na madaragoni, mimuya ya silivhindi, I bvani muthuni hoyu...amen," meaning "The God of Abraham, the God of Jacob, the God of Isaac...You spirits of diabolos and dragons, spirits of wickedness, get out of this animal...Amen." This he would do in case the animal may have been inhabited by wicked spirits which would have influenced it to harm him. However, that Mphagi would communicate with animals is not sufficient evidence to claim that he was Christian, and that he did that by means of Christian power either. This assertion could be substantiated by the fact that many others ahead of Abel Mphagi who were never postulated as being religious - especially with regards to Christianity, Mandevu for example, have been known also to have communicated with animals (Mafukata 2015a). The animals would hear and obey them. Moreover, Mphagi's abilities in this regard could still be explained in terms of the postulation submitted by Frankle and Stein (2005) where the authors indicate that men who would be called tokabitam; that is, 'man with knowledge' in the Trobriand Islanders off the western coast of New Guinea for example, have such complex knowledge to perform the 'magic' as performed by Abel Mphagi in this case study.

\section{Abel Mphagi and his Miraculous Healing Powers of Animals}

Abel Mphagi was a man who lived by prayer. He prayed to obtain results. Mphagi would pray and heal both sick people and animals. His healing power was instant. In case he failed to get the sick healed, Mphagi would disappear into the mountains to spend time fasting and praying - until news reached him that the patient was healed (Mukhadakhomu 2015; Nematshema-Nemauluma 2015). Mphagi is said to have prayed and healed sick animals such as donkeys, cattle, goats and dogs in various homesteads in villages which he frequented. One eye-witness respondent remarked "He [Mphagi] arrived at a homestead here at Mauluma Village one good morning and found a sick donkey. He [Mphagi] prayed for the donkey, and the donkey was healed instantly." At Tshituni Village, before Piet Khunwana Nematshema together with his family could relocate to Tshigodini at Mauluma Village, Mphagi arrived at the Khunwana-Nematshema's household only to find one of Khunwana-Nematshema's favourite bulls had died. Mphagi prayed for the bull, the animal awoke and began to run in full view of the residents.

Rakumbani-Luthaga (2016) also reported a similar incident when Mphagi, together with Silas Nematswerani of Matswerani, Maelula Village, prayed one day for a dead cow which woke up in full view of residents. Also at Vuvha Village (Muvhali 2016) Mphagi raised up a cow which had been dead for one full day because Mphagi had wanted to use the cow to pay for Nematswerani's younger brother's lobola for a bride. At the Mukhadakhomu compound at Mauluma Village - approximately 1955 - Mphagi arrived to find a sick bull in their kraal which had developed fits and these would plague him from time to time. The day Mphagi arrived, the bull had such a fit. He prayed for the bull, and the bull responded. 
Mphagi prophesied over the bull and proclaimed that the animal would never again develop fits, and that the animal would be the most productive and resourceful animal in the Mukhadakhomu herd. Indeed, Mphagi's prophesy was fulfilled because the Mukhadakhomus used that bull for years in their field for cultivation, and later sold the bull for some good cash at a livestock auction (Mukhadakhomu 2015).

It is common for religious personalities to be associated with miraculous claims such as these of Abel Mphagi. For example, Engenas Lekganyane of the Zion Christian Church (ZCC) is said to have prayed for, and raised a dead dove (De Visser, 2011). It appears Abel Mphagi was fond of animals as evidenced by most of his miracles involving animals. In fact, he had immense love for animals (Mukhadakhoumu 2015). Mphagi would be heard often chastising those who hurt animals. Mphagi would also protect wild animals such as snakes and other dangerous species from harm by humans. In the same way as both Clah and Moses, Abel Mphagi's theology was distinct from that of the Western missionaries in Vendaland who were not into the miracles, Gospel and prophesies. Mphagi had brought a strange religion to Vendaland. At that time locals were largely conversant and exposed to folk medicine to address human illnesses, which they received by consulting traditional healers, diviners (diagnosticians) and medicine persons who used ancestral powers to perform such miracles. These miracle workers would for example be physicians; herbalists; bone setters and/or paediatricians (Uche 2014). Mphagi was strange to the locals because his miracle-working powers hinged on what the locals would call the White man's religion and prayers.

Mphagi's miracle healing powers were often accompanied by prophesies. This article re-visited some of Mphagi's major prophesies. While figures such as Credo Mutwa are known to have predicted and prophesied a few things which later came to pass, Abel Mphagi is also known for having prophesied things which came to pass. According to Rakumbabi-Luthaga (2016) and Mukhadakhoumu (2015) Mphagi is said to have prophesied, approximately in 1938, that there would come a time when people would be drinking bottled water which would be sold for profit. This was fulfilled just in the early 2000 or so in South Africa when bottled mineral water began to be distributed and sold in retail stores.

Mphagi prophesied (approximately 1940/41) that people would be put in 'modern demarcated stands' (zwitentsi), and during that time husbands would forfeit household dominance because their wives would also be entitled to the ownership of such stands. This was to be fulfilled in approximately 1959 when the Vhavenda were resettled into demarcated pieces of land (zwitentsini) (Mukhadakhomu, 2015). Because of the uniqueness and strange way of doing mission - especially with regard to Abel Mphagi's miraculous healing practices and prophesies - that developed certain perceptions among the locals on Mphagi and his ministry. Thus the next section profiles these perceptions.

\section{Perception of Locals on Mphagi: The Comparatives between Others and Himself}

While Mphagi was thus viewed by some of the villagers of bringing the strange 'White man's culture' fermenting 'cultural conflict and discord' (Bogopa 2010) to the villagers, he was also seen as a victim of European religions brought by colonisers of the indigenous peoples to dismantle African cultural belief systems. It is indisputable that Mphagi's beliefs and practices were in direct contrast to popular social practices, and therefore a challenge to both religious and the indigenous world views. Africans are known to have deep-rooted beliefs in their ancestral world characterised by 'mystical' powers and authority and belief 
that the same provided magical supernatural powers to the living (Bogopa 2010; Mildnerová 2014). This belief would lead to "adherents with a sense of rootedness, an anchor and or identity" amongst Africans (Bojuwoye 2013) although ancestral worship and other cultural practices of the indigenous Africans would, in the main consider some form of 'primitive religions' (Bogopa 2010) by the missionaries and those who had been Christianised. Evidently, the disregard of African indigenous faiths by these groups postulated a lack of 'cross-cultural tolerance and respect' (Bogopa 2010) of the worldviews of others - in this case, indigenous Africans. The created theory in this regard is that indigenous Africans never had a worldview, and most European colonisers of Africa and their associates - religion; Christianity in particular - suggested that these agencies were to establish some form of worldview for Africans. As such, efforts were made to systematically dismantle everything that was characteristic of an African viewpoint by replacing it with Eurocentrism. The dismantling of the indigenous African viewpoint especially as, and when it involves beliefs in ancestral worship and belief systems - would subsequently and effectively strip off what was Africa, for Africa without its indigenous identity specified by religion, culture and values had lost its social practice. In other words, Africa became an extension of Europe and whatever Africans were doing was determined by Westernisation. This view could be substantiated by the postulation opined by Manus (2007) when arguing that current Igbo generations - both in Nigeria and the diaspora - had lost that Igbo identity mainly as a result of Westernisation and modernity.

Other villagers postulated that Abel Mphagi had actually unknowingly received his newly-found Christian faith from his ancestors. It is common amongst Africans to find some who would always believe that their ancestors still operated even if it meant through modern Christian missionaries. In fact, the denial and prohibition of the indigenous Africans from combining ancestral beliefs with Christian values, assisted greatly towards the emergence of African Independent Churches (AICs) in most parts of Africa in protest of the Africans against what they thought was "cultural imperialism undertaken by the missionary representatives of the historic mission churches" of the colonial White European missionaries (Mildnerová 2014). In other words, African Independent Churches (AICs) used their faith to wage political resistance against colonial tendencies of the Europeans acting as custodians of a rising cultural renaissance movement against what the Africans thought was colonial imperialism and dominance of the Africans by the Whites (Mildnerová 2014).

A famous African Independent Church (AIC) to emerge in South Africa is the Zion Christian Church (ZCC) of Engenas Lekganyane of GaMamabolo in the former Lebowa Bantustan of South Africa (De Visser 2011). Engenas Lekganyane is widely believed to have been a product of John Alexander Dowie of the Zion City movement from Illinois in the United States of America (Mafuta, 2010). However, the ZCC, like all other indigenous African churches, has received wide interrogation by some critics who question the Church's Christianity (De Visser, 2011). Elsewhere, there emerged various indigenous African Independent Churches (AICs) such as the Lumpa Church of Alice Lenshina in Zambia which emphasised prophecy and healing conveyed through traditional methods of healing combined with "Christian healing means of prayers; spiritual blessings; laying on of hands on patients and demon exorcism" in their theology, believing that "the origin of human suffering lies in the world of invisible powers such as demons, witches and fallen angels" (Mildnerová 2014; Ndung'u 2009).

When Engenas Lekganyane; founder of the seven million members (de Visser 2011) strong Zion Christian Church (ZCC), returned from Johannesburg to GaMamabolo with his 
newly-found Christian version of worship characterised by some healing powers, it was the people of GaMamabolo - especially his family - who were quick to say Lekganyane's Badimo (ancestors) were working in him. It is evident that most Africans in many subregions of Africa would always link their indigenous beliefs with the newly-found religious references. Truter (2007) argues that even "African traditional healing is ... intertwined with cultural and religious beliefs, and is holistic in nature. It does not focus only on the physical condition, but also on the psychological, spiritual and social aspects of individuals, families and communities". The suggestion here is that every form of supernatural power, as in the case of Abel Mphagi and Engenas Lekganyane's healing powers for example, would be thought to address the above.

The link of Lekganyane and Abel Mphagi's supernatural healing powers and exploits with the power of ancestors working in them, is actually not surprising given that Bojuwoye (2013) found that some indigenous Africans in fact believed that "ancestors are ... capable of controlling events in life" - and as such, no matter how deeply-rooted some of these indigenous peoples become in orthodox Christianity for example, they still found their way into indigenous faiths practices - even to an extent of consulting sangomas (diviners) as mediums with ancestral spirits (Truter 2007). Mafukata (2015b) also corroborates this assertion. Despite Westernisation and Christianisation of most of Africa's indigenous peoples such as the Igbo of Nigeria, most of these groups would still cling to their indigenous faiths with preservation of most of the practices (Stevenson, 1985; Manus, 2007).

Evidently, it is hard for Africans to separate their indigenous faith in ancestral influence of the living with any other religion entirely and wholly, whether they subscribed to Christianity or not. Phaswana (2000) also shares this assertion. Kumalo (n.d) illustrates this better. Kumalo (n.d) reported that Professor Gabriel Setiloane, a hardened Methodist Christian who was Tswana by culture had in fact "received his faith from his ancestors who had come into contact with the Methodist missionaries". This assertion opines that despite Professor Setiloane's postulated civilisation through his Methodist Christianisation and high levels of modern education, the professor and those around him still would not 'see any contradictions' between African traditional culture and Methodist Christianity. In addition, Phaswana reports that, as a Muvenda - despite being a Christianised Lutheran, and an academic - even during his marriage, he had to still observe and honour all the cultural rites on his bride as demanded by his family elders (Phaswana 2000). If a Christianised university professor such as Gabriel Setiloane could not find it easy to break away totally from his culture, what more the ordinary illiterate indigenous African?

\section{Abel Mphagi's strange Christianity and his strange Cultural Practices: The Clash of the White Man's Religion and the Black Man's Culture and Tradition}

Whether Abel Mphagi was Christian or not, the locals still saw in him a man who was a product of his own ancestors - and his miracles therefore influenced by these ancestors. The locals would often ask "what kind of a man is this?" each time Mphagi performed a miracle in the village. One day at Dopeni Village during an evening Church service at the compound of Vho (Mr) Jakubosi Tshilebvu Matshidza, another local preacher affiliated to a local Zionist Church, Abel Mphagi arrived and found believers singing and dancing in one of Jakubosi's mud huts where people were holding an evening Church service. Abel Mphagi entered the hut, stood at the centre and greeted the people 'mulalo!' meaning 'peace unto you' and started preaching from Mark 16:15. His teaching was on "they will 
carry venomous snakes in their hands, and they shall never harm them". In full view of the ecstatic worshippers, Abel Mphagi pulled out a highly venomous snake from his Tshidzhoni (coat) which he was given by White people while incarcerated at Louis Trichardt police cells. While preaching, Mphagi, in awe of everyone, threw the snake at the worshippers who scattered everywhere to get away from the slithering snake in the mud hut. He immediately picked up the snake and put it back into his Tshidzhoni (coat) and left the meeting. Evidently, though Mphagi was known to be a strict prophet, the snake incident at the Tshilebvu compound showed the other side of his life - that he was that prophet with a high sense of humour. Snakes are associated with witchcraft among the Vhavenda - and anyone who has dealings with snakes is often stigmatised for witchcraft. Although many people still felt Mphagi was a prophet, a few others, because of this incident, felt he was a magician or a witch. This incident made some people fear him. However, others still felt Mphagi was rather a great man of God with some kind of unique holiness because the Scripture in Mark 16 was fulfilled at their witness through this incident. Mphagi's humour would also be evident from how he would use the story of King Nebuchadnezzar and his subsequent punishment by God as recorded in the Book of Prophet Daniel Chapter four in Verse 25 to tease people humorously. Mphagi would tell the people that those who did not show fear of God would one day feed on grass the same way as Nebuchadnezzar did. About this, Mphagi would be heard laughing long and hard (Rakumbani-Luthaga 2016).

Abel Mphagi's healing powers were strange and unusual amongst the villagers especially considering the fact that the powers of the so-called 'Bible God' were something new and foreign as most of these villagers were not exposed to Christianity and this 'Bible God,' but their ancestral deities, rituals and practices. In other words, social life, and, amongst others, primary health care service were issues of traditional practices dependent on ancestral deities involving the use of traditional medicines and spiritual consultations (Truter 2007). This culture is hard to break despite growth and entrenchment of Christianity and European civilisation in most parts of the African region in general. For instance, in the modern dispensation, there were approximately 200000 practising traditional healers versus 25000 modern doctors in South Africa only (Truter 2007). This explains why a number of practising Christians in South Africa, in particular, would still resort to their indigenous practices of addressing those issues of life found to be unexplainable (Kumalo n.d; Mafukata 2015b; Truter 2007).

Based on the belief systems of the locals, it is understandable why some amongst the respondents even opined that Abel Mphagi was used by his people's Vhadzimu (ancestors), but only using the Bible to perform his magical healing powers. Amongst most African communities, using ancestral powers is a common aspect of theology and cultural practices in issues concerning 'diagnostically unexplainables' (Truter 2007) in illnesses, bad luck, magic and witchcraft amongst others. Ancestral power would also be used especially against those who transgressed certain standards involving individuals or tribal groups (Dowden 2014). According to Dowden (2014), curses could be pronounced over transgressors and some bad luck would befall them. Although Mphagi never used his powers to curse people, the locals still 'feared' him, and the fact that if he could have power to pronounce healing miracles - especially over sick people and animals - he could still use the same powers to curse those who transgressed against him. The fear that some people had for Mphagi was confirmed one day when a white man who had kicked Mphagi in the groin, suddenly found his leg swelling to become terribly heavy to carry. This incident took place at Tshamuya where Mphagi was clearing the bush in order to build a house for himself. The white man arrived and tried to stop Mphagi, and an altercation ensued. In 
anger, and with disdainful disregard of Mphagi as a Black man, the White man kicked Mphagi in the groin. Without Mphagi saying anything, the White man's leg began to swell. The White man reported the matter to the Louis Trichardt police who took Mphagi in. The following day, the police found him outside the police holding cells. When they asked him who had opened the locked doors for him, he told them his God had done so.

This occurred on two successive days. At that stage the White men gave Mphagi a Bible and a Tshidzhoni (coat) and released him. Although many amongst the locals saw the powerful God of Abel Mphagi in action in this incident, there were some key informants who submitted that some amongst those locals began instead to construe Mphagi as a witch practising witchcraft. In fact, there were some locals who were of the opinion that Mphagi was indeed a witch, and had practised witchcraft. Some began to call Mphagi a magician. However, given the definition of what a magician was, as postulated by veteran anthropologist Edward Taylor who did some useful studies on witchcraft, magic and religion in his famous book entitled 'Primitive Cultures' which was published in 1871 (Frankle and Stein 2005), the description of Mphagi as a magician or witch would be in contrast and therefore contestable.

Other scholars of magic such as James Frazer and Émile Durkheim (Frankle and Stein 2005) in the same way as Edward Taylor would also have contested that definition. Evidently, there is a clash between Abel Mphagi's religious practices and his cultural and traditional values and philosophy which eventually explain the somewhat misty understanding which locals continue to have about him. The question needing further interrogation is whether Mphagi was indeed a Christian or a traditional culturalist with some practices he would call Christian. However, after the dust has settled on issues of Abel Mphagi the majority of those who knew him in person, and even those who have some doubts of his Christianity, concede that he was indeed a Christian - however, with certain inexplicable supernatural powers and deeds.

\section{Conclusion}

The main aim of this article was to investigate, highlight and present the life and ministry of Abel Mphagi because it has not received the recognition it deserves - especially in literature and debates concerning the growth and expansion of Christianity in Vendaland. On the one hand, the specific objective of this article was to demonstrate the contrast between African indigenous Christian missionaries and their practices, and Western missionaries operating in Vendaland during the Abel Mphagi era. This article could provide an archive on the life and ministry of this virtually forgotten spiritual giant called Abel Mphagi who played a major role in the growth and expansion of African indigenous Christianity in Vendaland.

Generally viewed, Abel Mphagi and his theology were difficult to understand. Nothing clearly linked him to indigenous faith while it was also not conclusive that his was Christianity grounded in missionary teachings operating and dominant in the area at that time. If Mphagi could not be linked with the missionary teachings, there arises a critical question with regard to the origin of his Christianity and miraculous healing powers. Although he preached and persuaded some to fear God, he never baptised anyone, neither did he ever recruit those who believed into a particular Church group. Because of Mphagi's approach of non-affiliation to a particular church group, he avoided confrontations with his peers. His non-affiliation to a particular church group meant that Mphagi operated as a freelancer. Mphagi reported to no one church organisation, and therefore owned no one an explanation of how he did ministry. He propagated a simple Gospel of love amongst the 
villagers in his dominant approach of humanism. Abel Mphagi never carried a Bible around, and seldom read from the Bible in public. He would, however, from time to time refer to the Bible quoting various verses by heart. It remains unclear whether Mphagi could even read and write. The majority of people who were his peers at that time, where illiterate because formal school education was still rare in Vendaland. However, a few such as Marole could read and write (Mafela 2008). Abel Mphagi was a strange African indigenous evangelist, prophet, healer, apostle and missionary. Despite Mphagi's contribution to the growth and expansion of African indigenous Christianity in Vendaland, Mphagi is not included in the recordings and retelling of such history.

\section{BIBLIOGRAPHY}

Agbiji, OM \& Swart, I 2015. Religion and Social Transformation in Africa: A Critical and Appreciative Perspective. Scriptura 114 1:1-20.

Agyekum, K 2006. The Sociolinguistic of Akan Personal Names. Nordic Journal of

African Studies 15, 2:206-235.

Amoah, J \& Bennett, T 2008. The Freedoms of Religion and Culture under the South

African Constitution: Do Traditional African Religions enjoy equal Treatment?

African Human Rights Law Journal 2008, 8:357-375.

Boeyens, JCA 2012. The Intersection of Archaeology, Oral Tradition and History in the

South African Interior. New Contree, July 2012, 64:1-30.

Bogopa, D 2010. Health and Ancestors: The Case of South Africa and Beyond. Indo-

Pacific Journal of Phenomenology 10, 1:1-7.

Bojuwoye, O 2013. Integrating Principles Underlying Ancestral Spirits Belief in

Counselling and Psychotherapy. Ife Psychologia 21, 1:74-89.

Boshoff, W 2004. The Bakopa of Boleu and the Missionaries from Berlin (1860-1864): The

Brief Existence of Gerlachshoop, First Mission Station of the Berlin Missionary

Society in the ZAR. Missionalia 32, 3:445-471.

Brock, P 2011. The Many Voyages of Arthur Wellington Clah. UBC Press, Toronto.

Brock, P 2003. Two Indigenous Evangelists: Moses Tjalkabota and Arthur Wellington Clah.

The Journal of Religious History 27, 3:348-366.

Christian, NG 2014. The Impact of Climate Change on African Traditional Religious

Practices. Journal of Earth Science and Climatic Change 5, 7:1-5.

doi:10.4172/2157-7617.1000209.

Crafford, D (ed.) 1991. Trailblazers of the Gospel: Black Pioneers in the Missionary

History of Southern Africa. Pretoria: IMR, University of Pretoria.

De Visser, A 2011. Honoured, but Eclipsed: Beliefs About Christ in an African Church.

Paper for Evangelical Theological Society, San Francisco. Nov. 16.

Dowden, R 2014. Africa: Altered States, Ordinary Miracles. London: Portobello.

Draper, M 2003. In Quest of African Wilderness. USDA Forest Service Proceedings

RMRS-P-27. 2003:57-62.

Fernandez, JW 2001. The Precincts of the Prophet: A Day with Johannes Galilee Shembe.

Journal of Religion in Africa $\mathrm{V}(1)$.

Frankle, RLS \& Stein, PL 2005. Anthropology of Religion, Magic, and Witchcraft. Boston,

MA: Allyn \& Bacon. 
http://scriptura.journals.ac.za

(Vho) Abel Mphagi - The Barefooted Native 'Prophet' and 'Evangelist' of Vendaland

Hassan, TL 2015. Attitudes of Christian Missionaries towards African Traditional

Religious Beliefs in East Africa during the British Colonial Rule. African Journal of History and Culture 7, 10:193-199. DOI:10.5897/AJHC2015.0276 Article Number: 5D944D155369.

Kamwaria, A \& Katola, M 2012. The Role of African Traditional Religion, Culture and World-View in the Context of Post-War Healing among the Dinka Community of Southern Sudan. International Journal of Humanities and Social Science 2, 21:49-55.

Kanu, IA 2014a. Symbols in African Philosophy and the Issue of Nation Building. International Journal of Scientific Research 3, 9:426-428.

Kanu, IA 2014b. African Traditional Religion in a Globalizing World. International Journal of Humanities Social Sciences and Education 1, 8:4-12.

Kirkaldy, A 2010. Klaas Koen: Identity and belonging in the Berlin Mission Society during the late Nineteenth Century. Historia 55, 2:99-120.

Khorommbi, NL 1996. Echoes from beyond a Pass between Two Mountains. Pretoria: University of South Africa.

Khorommbi, NL 2001. Lutherans and Pentecostals in Mission among the Vhavenda - A Comparative Study in Missionary Methods. Unpublished PhD Thesis, University of South Africa, Pretoria.

Khumela, M 2017. Interview held at her Homestead at Mauluma Village: 08 March 2017. Kumalo, RS 2014. Religion and Politics in the Heritage of Untsikama ka Gaba and its Relevance to a Democratic South Africa. Studia Historiae Ecclesiastical 40, 1:21-37. Kumalo, S (n.d) 2016. Methodism in South Africa: The teaching Ministry of five Native Mission Agents. School of Theology and Religion University of KwaZulu Natal. Accessed 15 July 2016 from http//www.http://uir.unisa.ac.za/bitstream/handle/ 10500/4388/Kumalo.pdf? sequence=1\&isAllowed $=\mathrm{y}$.

Mabogo, DEN 1990. The Ethnobotany of the Vhavenda. Unpublished Magister Dissertation, University of Pretoria, Pretoria.

Mafela, MJ 2008. LT Marole: A Forgotten Pioneer in Tshivenda Lexicography. Lexikos 18 (AFRILEX-reeks/series 18:366-373. Paper presented at the Eleventh International Conference of the African Association for Lexicography, organized by the Tshivenda National Lexicographic Unit, University of Venda for Science and Technology, Thohoyand Vou, Republic of South Africa, 5-7 July 2006.

Mafukata, MA 2015a. Mandevu. Journal of Arts and Humanities 4, 1:14-26.

Mafukata, MA 2015b. Mythical Leopards (panthera pardus) of the Vhavenda. International Journal of Information Research and Review 2, 07:836-852.

Mafuta, L 2010. Religion and Development in South Africa: An Investigation of the Relationship between Soteriology and Capital Development in an African Initiated Church (AIC). Unpublished DTh, University of South Africa, Pretoria.

Manus, UC 2007. The Sacred Festival of Iri Ji Ohuru in Igboland, Nigeria. Nordic Journal of African Studies 16, 2:244-260.

Martey, E 2006. Prophetic Movements in the Congo: The Life and Work of Simon Kimbangu and how his followers saw him. Journal of African Instituted Church Theology 11, 1:1-17.

Mashau, TS 2012. Multi-Cultural Education: Is Education playing a Role in Acculturating Different Cultures in South Africa? American International Journal of Contemporary Research 2, 6:57-65. 
Mbiti, JS 1969. African Religions and Philosophy. London: Heinemann.

Mildnerová, K 2014. African Independent Churches in Zambia (Lusaka). Ethnologia Actualis 14, 2:8-25. doi: 10.1515/eas-2015-0001.

Mokotso, RI 2015. Syncretism of Basotho Traditional Religion and Christianity: Gateway to the Syncretistic Teaching of Basotho Traditional Religion and Christianity in Lesotho Schools. African Journal of History and Culture 7, 7:157-163, DOI: 10.5897/AJHC2015.0260 Article Number: F4E357753819.

Mukhadakhomu, D 2015. Interview held at his homestead at Mauluma Village: 16 April 2015.

Mulaudzi, FM 2007. Indigenous Health Beliefs, Attitudes and Practices among VhaVenda: A Challenge to the Promotion of HIV/AIDS Prevention Strategies. Curationis 30, 3:31-37.

Munyai, AS 2007. Understanding The Christian Message in Venda: A Study of the Traditional Concepts of God and of Life Hereafter among the Venda, with reference to the Impact of these Concepts on the Christian Churches. Unpublished MA Dissertation, University of Pretoria, Pretoria.

Mutavhatsindi, MA \& Meiring, PGJ 2014. Church planting in South Africa: The role of the Reformed Church Tshiawelo. Verbum et Ecclesia 35, 1):1-7.http://dx.doi. org/10.4102/ve.v35i1.424.

Muvhali, G 2016. Interview held at his homestead at Murunwa Village: 11 August 2016.

Ndou, RM 1993. The Vhavenda Concept of Life hereafter: A Comparison between the traditional Venda Religion and the Christian Tradition. Thohoyandou: University of Venda.

Nematshema-Nemauluma, D 2015. Interview held at her homestead at Mauluma Village: 11 November 2015.

Ndung'u, NW 2009. Persistence of Features of Traditional Healing in the Churches in Africa: The Case of the Akurinu Churches in Kenya. Thought and Practice: A Journal of the Philosophical Association of Kenya (PAK) New Series 1, 2:87-104.

Njoku, FOC 2004. Development and African Philosophy: A theoretical Reconstruction of African socio-political Economy. New England: Universe.

Nwoye, CMA 2011. Igbo Cultural and Religious Worldview: An Insider's Perspective. International Journal of Sociology and Anthropology 3, 9:304-317.

O’Brien, J, Remenyi, D \& Keaney, A 2004. Historiography - A Neglected Research Method in Business and Management Studies School of Systems and Data Studies, Trinity College Dublin, Ireland. Electronic Journal of Business Research Methods 2, 2:135-144.

Onyeozili, EC \& Ebbe, ONI 2012. Social Control In pre-colonial Igboland of Nigeria. African Journal of Criminology and Justice Studies 6, 1 \&2:29-43.

Peires, JB 1987. The Central Beliefs of the Xhosa Cattle-killing. Journal of African History 28:43-63.

Phaswana, NS 2000. Marital Problems in religiously mixed Marriages amongst the Vhavenda People of South Africa: An African-Christian Perspective. Unpublished DLitt et Phil. Thesis, University of South Africa, Pretoria.

Pretorius, H 2003. Strange are the Ways of Zion: a Coloured Zionist Pioneer. 153-172. In Cuthbertson, G, Pretorius, H \& Daneel, I. Frontiers of African Christianity: Essays in honour of Inus Daneel. African Initiatives in Christian Mission, University of South Africa, Pretoria. 
Rakumbani-Luthaga, TD 2016. Interview held at her homestead at Murunwa Village: 11 August 2016.

Ramigo-Ramovha, RS 2016. Interview held at Rabali Village: 12 May 2016.

Ravhanna, NE 2016. Interview held at her homestead at Murunwa Village: 11 August 2016. Semenya, SS \& Potgieter, MJ 2014. Bapedi Traditional Healers in the Limpopo Province, South Africa: Their socio-cultural Profile and Traditional Healing Practice. Journal of Ethnobiology and Ethnomedicine 10, 4:1-12.

Sheikman, MB 2004. Zulu Shaman: Dreams, Prophecies, and Mysteries. Psychiatric Services, Book Reviews 55, 8:950-951.

Stevenson, I 1985. The Belief in Reincarnation among the Igbo of Nigeria. Journal of Asian and African Studies XX, 1-2:1,3-30.

Truter, I 2007. African Traditional Healers: Cultural and Religious Beliefs intertwined in a Holistic Way. SA Pharmaceutical Journal, September 2007:56-60.

Uche, NI 2014. Resilience of Folk Medicine among the Igbos of Southeast Nigeria. European Scientific Journal 10, 36:177.187.

Wepener, C 2015. African Therapy for a Fractured World(view): The life of Founder Bishop Johannes Richmond and the Invention of Tradition and Group Cohesion in an African Initiated Church. HTS Teologiese Studies/ Theological Studies 71(1)1-9.http:// dx.doi.org/10.4102/hts. V71i1.2900. 